Brit. Heart F., 1966, 28, 414.

\title{
Effect of Propranolol (Inderal) on Exercise Tolerance in Angina Pectoris
}

\author{
J. HAMER ${ }^{\star}$, T. GRANDJEAN, L. MELENDEZ, AND G. E. SOWTON \\ From the Institute of Cardiology and the National Heart Hospital, London W.I
}

Clinical studies in patients with angina pectoris have suggested a beneficial effect following specific blockade of the beta-adrenergic sympathetic nerves that are responsible for autonomic stimulation of the myocardium (Dornhorst and Robinson, 1962; Apthorp, Chamberlain, and Hayward, 1964). The present study is designed to assess the effect of a potent beta-adrenergic blocking agent, propranolol (inderal), on an objective measurement of exercise tolerance in patients with angina pectoris. A preliminary investigation (Hamer et al., 1964) suggested a favourable response in some subjects. In the present work we are particularly concerned to exclude a non-specific effect and to define the indications for cardiac sympathetic blockade.

\section{SubJeCtS AND MethodS}

A selected group of 14 patients was studied by means of a standardized exercise tolerance test, as in the preliminary investigation (Hamer et al., 1964). Patients with any evidence of left ventricular failure were excluded, and each patient was limited by angina (or in two cases because of depression of the S-T segment in the electrocardiogram) in an initial exercise test and in tests performed after a placebo injection and after propranolol.

All the patients were having angina of effort of moderate severity during the course of their daily activities, and there had been no change in their condition in the last three months. Patients with angina at rest or on slight exertion were not studied. No patient with a casual diastolic blood pressure greater than $100 \mathrm{~mm}$. Hg, or with valvar disease, was included in the investigation. Patients with left ventricular failure were excluded on the basis of a history of dyspnœa on exertion, the presence of atrial or third heart sounds or delayed aortic valve closure, or radiological evidence of left ventricular enlargement or pulmonary venous congestion. Twelve

Received August 25, 1965.

$\star$ Present address: St. Bartholomew's Hospital, London, E.C.1. patients presumably had coronary arteriosclerosis, but in 2 there was evidence of other types of coronary artery disease; one (S.P.) had polyarteritis nodosa in a quiescent phase, and in another (P.S.), a woman aged 40, there was positive serology, suggesting that the angina might be due to coronary ostial stenosis.

In all, 11 men and 3 women were studied, and their ages were between 40 and 69 years. Angina had been present for at least a year, and in some cases for much longer (Table I); most patients had been under observation in the clinic from the onset of symptoms. Major cardiac infarction bad occurred in 4 subjects, in each case posteriorly, from 2 to 9 years previously. In 4 further subjects minor anterior ischæmic changes had occurred from 1 to 3 or more years earlier, but had subsequently regressed. No infarction had occurred in the remaining 6 patients, but 3 had persistent but minor (less than 1 mm.) depression of the S-T segments in the "left ventricular" leads (I, VL, V5, and V6).

The nature of the test was explained to the patients and their agreement was obtained before the study was begun. The patients were exercised in the sitting position on a Schönander-Elema bicycle ergometer (Holmgren and Mattsson, 1954) which maintains a constant load with wide variations in the rate of pedalling, and were warned that they must stop bicycling at the onset of angina. Exercise was begun at a work level of 100 kilopond-metres (kpm.) a minute (16 watts), and the load was increased at 6 -minute intervals by $200 \mathrm{kpm} . / \mathrm{min}$. (33 watts). The electrocardiogram was monitored throughout the study, using a modified CR5 lead. Depression of the S-T segment was found in 9 patients, and in 2 there were multiple ventricular extrasystoles in the initial and placebo studies, but not after propranolol. Similar S-T segment changes were found in each of the three exercise periods (Fig. 1). In 2 patients exercise was stopped on instruction in each part of the study before the onset of angina because of the appearance of major S-T segment displacement in the electrocardiogram. The angina produced during the test resembled the patient's natural attacks and passed off quickly when exercise was stopped. Any electrocardiographic changes were followed at intervals until the resting pattern returned. 
TABLE I

CLINICAL FINDINGS IN THE 14 PATIENTS STUDIED

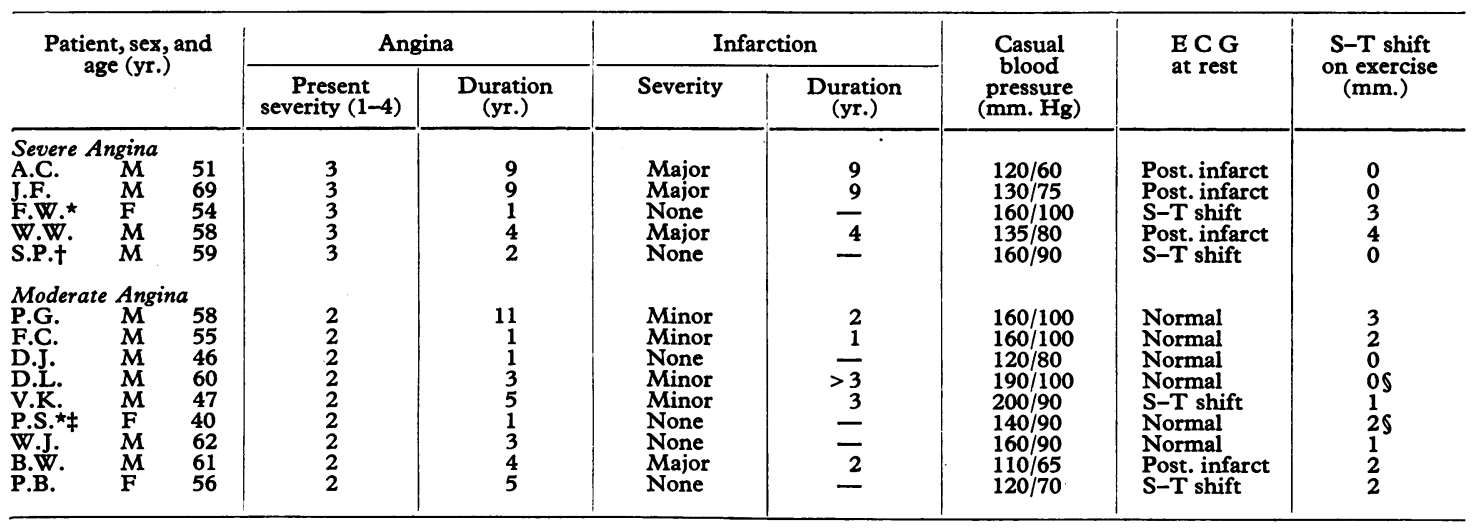

* Stopped by S-T depression in exercise test + Polyarteritis nodosa.

The patients were allowed to rest for 30 minutes between each part of the test. An intravenous injection of normal saline was given 15 to 20 minutes before a second exercise test, and this was followed by a third test 15 to 20 minutes after an injection of $5 \mathrm{mg}$. of propranolol. The patients were not aware which injection contained the active agent. The total work performed in each test was calculated, and the heart rate was obtained from the electrocardiogram at rest and after 2,4 , and 6 minutes at each work load.
₹ Positive serology.
Ectopics on effort, except after propranolol.

\section{ResUlts}

The total work performed by each subject in the initial test, after a placebo, and after propranolol, is shown in Table II. The patients fell into two groups: 5 subjects had severe angina as judged from an initial exercise tolerance of less than $600 \mathrm{kpm}$. (i.e. $6 \mathrm{~min}$. at $100 \mathrm{kpm} . / \mathrm{min}$.), and the remaining 9 subjects had only moderate angina with an initial

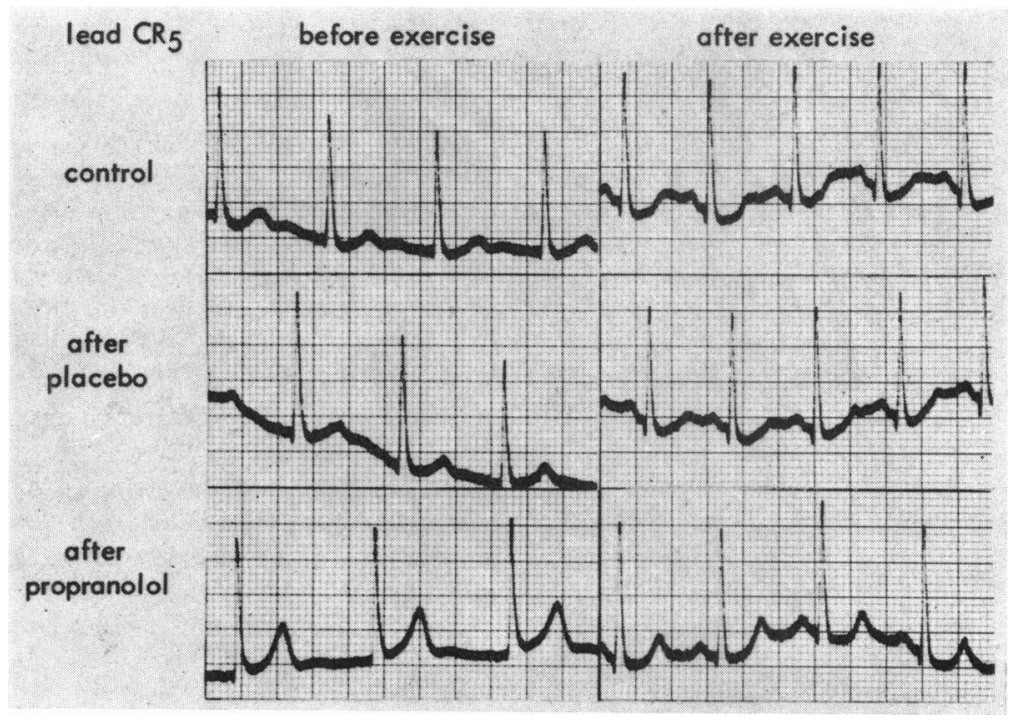

FIG. 1.-The electrocardiogram before and after exercise in a representative subject. Similar changes in the S-T segment are evident immediately after exercise in the initial (control) test, following a placebo, and after propranolol. Angina was produced by the exercise in each test. The slower heart rate after propranolol is apparent both before and after exercise. 
TABLE II

EXERCISE TOLERANCE BEFORE AND AFTER INJECTION OF SALINE OR OF PROPRANOLOL IN 14 PATIENTS LIMITED BY ANGINA PECTORIS

\begin{tabular}{|c|c|c|c|c|c|c|c|c|c|c|c|c|}
\hline \multirow{3}{*}{ Subject } & \multicolumn{3}{|c|}{ Total work (kpm.) } & \multicolumn{3}{|c|}{ Percentage change } & \multicolumn{3}{|c|}{ Heart rate on exercise ${ }^{\star}$} & \multicolumn{3}{|c|}{ Percentage change } \\
\hline & \multirow[t]{2}{*}{$\begin{array}{c}\text { Initial } \\
\text { test }\end{array}$} & \multirow[t]{2}{*}{$\begin{array}{c}\text { After } \\
\text { placebo }\end{array}$} & \multirow{2}{*}{$\begin{array}{c}\text { After } \\
\text { pro- } \\
\text { pranolol }\end{array}$} & \multirow{2}{*}{$\begin{array}{l}\text { After } \\
\text { placebo } \\
\text { (from } \\
\text { initial } \\
\text { test) }\end{array}$} & \multicolumn{2}{|c|}{$\underset{\text { propranolol }}{\text { After }}$} & \multirow[t]{2}{*}{$\begin{array}{c}\text { Initial } \\
\text { test }\end{array}$} & \multirow[t]{2}{*}{$\begin{array}{c}\text { After } \\
\text { placebo }\end{array}$} & \multirow{2}{*}{$\begin{array}{c}\text { After } \\
\text { pro- } \\
\text { pranolol }\end{array}$} & \multirow{2}{*}{$\begin{array}{l}\text { After } \\
\text { placebo } \\
\text { (from } \\
\text { initial } \\
\text { test) }\end{array}$} & \multicolumn{2}{|c|}{$\begin{array}{c}\text { After } \\
\text { propranolol }\end{array}$} \\
\hline & & & & & $\begin{array}{l}\text { (from } \\
\text { initial } \\
\text { test) }\end{array}$ & $\left|\begin{array}{c}\text { from } \\
\text { placebo } \\
\text { response })\end{array}\right|$ & & & & & $\begin{array}{c}\text { (from } \\
\text { initial } \\
\text { test) }\end{array}$ & $\mid \begin{array}{c}\text { (from } \\
\text { placebo } \\
\text { response) }\end{array}$ \\
\hline $\begin{array}{c}\text { Severe Angina } \\
\text { A.C. } \\
\text { J.F. } \\
\text { F.W. } \\
\text { W.W. } \\
\text { S.P. }\end{array}$ & $\begin{array}{l}400 \\
350 \\
150 \\
450 \\
450\end{array}$ & $\begin{array}{l}900 \\
350 \\
200 \\
900 \\
250\end{array}$ & $\begin{array}{r}1050 \\
750 \\
300 \\
2050 \\
400\end{array}$ & $\begin{array}{r}123 \\
0 \\
33 \\
100 \\
-44 \\
\end{array}$ & $\begin{array}{r}162 \\
114 \\
100 \\
356 \\
-11\end{array}$ & $\begin{array}{r}17 \\
114 \\
50 \\
128 \\
60\end{array}$ & $\begin{array}{r}105 \\
94 \\
97 \\
117 \\
73\end{array}$ & $\begin{array}{r}99 \\
96 \\
92 \\
115 \\
72\end{array}$ & $\begin{array}{l}87 \\
83 \\
88 \\
97 \\
63\end{array}$ & $\begin{array}{l}-6 \\
+2 \\
-5 \\
-2 \\
-1\end{array}$ & $\begin{array}{r}-17 \\
-12 \\
-9 \\
-17 \\
-14\end{array}$ & $\begin{array}{r}-12 \\
-14 \\
-4 \\
-16 \\
-13\end{array}$ \\
\hline Mean & 360 & 520 & 910 & 42 & 145 & 84 & 97 & 95 & 84 & -2 & -14 & -12 \\
\hline $\begin{array}{c}\text { Moderate Angina } \\
\text { P.G. } \\
\text { F.C. } \\
\text { D.I. } \\
\text { D.I. } \\
\text { V.K. } \\
\text { P.S. } \\
\text { W.J. } \\
\text { B.W. } \\
\text { P.B. }\end{array}$ & $\begin{array}{l}1700 \\
2400 \\
2650 \\
4150 \\
2900 \\
3200 \\
3000 \\
1800 \\
3200\end{array}$ & $\begin{array}{l}2400 \\
2950 \\
2600 \\
3100 \\
4200 \\
2950 \\
3050 \\
3000 \\
2500\end{array}$ & $\begin{array}{l}3200 \\
3550 \\
2600 \\
3700 \\
4350 \\
3600 \\
4500 \\
3900 \\
3650\end{array}$ & $\begin{array}{r}41 \\
25 \\
-2 \\
-25 \\
45 \\
-8 \\
2 \\
67 \\
-22\end{array}$ & $\begin{array}{r}88 \\
48 \\
-2 \\
-11 \\
50 \\
13 \\
50 \\
133 \\
14\end{array}$ & $\begin{array}{r}33 \\
20 \\
0 \\
19 \\
3 \\
22 \\
48 \\
30 \\
46\end{array}$ & $\begin{array}{r}93 \\
91 \\
101 \\
104 \\
123 \\
127 \\
130 \\
110 \\
155\end{array}$ & $\begin{array}{r}89 \\
89 \\
102 \\
113 \\
112 \\
130 \\
130 \\
106 \\
155\end{array}$ & $\begin{array}{r}82 \\
79 \\
87 \\
82 \\
96 \\
110 \\
100 \\
93 \\
123\end{array}$ & $\begin{array}{r}-4 \\
-2 \\
+1 \\
+9 \\
-9 \\
+3 \\
0 \\
-4 \\
0\end{array}$ & $\begin{array}{l}-12 \\
-13 \\
-14 \\
-21 \\
-22 \\
-13 \\
-23 \\
-15 \\
-21\end{array}$ & $\begin{array}{l}-8 \\
-11 \\
-15 \\
-27 \\
-14 \\
-15 \\
-23 \\
-12 \\
-21\end{array}$ \\
\hline Mean & 2780 & 2970 & 3670 & 14 & 43 & 24 & 115 & 114 & 95 & -1 & -17 & -16 \\
\hline Over-all mean & 1910 & 2100 & 2690 & 24 & 79 & 48 & 110 & 108 & 91 & -1 & -16 & -15 \\
\hline
\end{tabular}

Significant changes in italics.

$\star$ After 6 minutes at the maximum work load reached in all 3 tests.

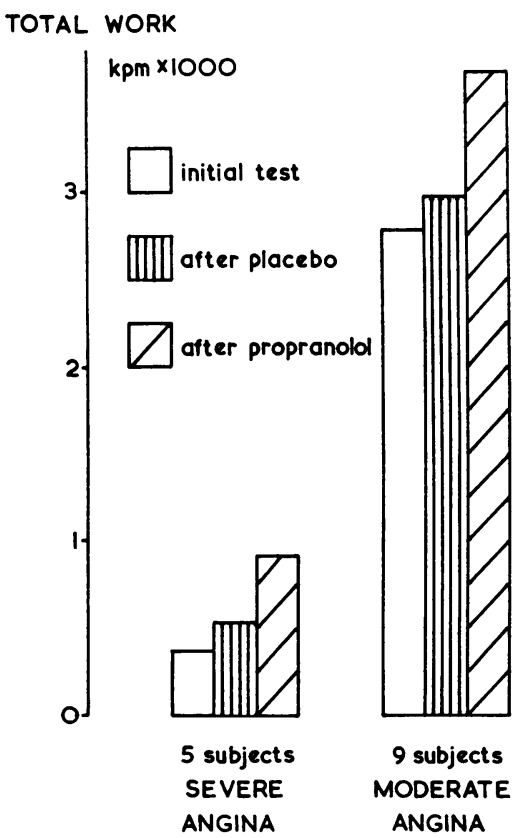

Fig. 2.-Total work performed in the graduated exercise test. The average exercise tolerance in an initial test, following a placebo, and after propranolol, is shown for the two groups of patients. There is a small placebo response and a greater increase in exercise tolerance after propranolol in each group. exercise tolerance greater than $1500 \mathrm{kpm}$. (6 min. at $100 \mathrm{kpm}$. $/ \mathrm{min}$. followed by $3 \mathrm{~min}$. at $400 \mathrm{kpm} . / \mathrm{min}$.).

The average changes in each group indicate a small placebo response and a greater increase in exercise tolerance after propranolol (Fig. 2). The placebo response in individual subjects varied considerably, and in 5 patients exercise tolerance was reduced after the placebo (Fig. 3). After propranolol exercise tolerance was greater than after the placebo, except in one subject who showed no change (Fig. 3).

In the 5 patients with severe angina there was a significant difference $(p<0.05)$ between the exercise tolerance after propranolol and the initial value. The 9 patients with moderate angina showed a highly significant increase beyond both the initial and the placebo response after propranolol $(\mathrm{p}<$ 0.005). The slowing of the heart on exercise after propranolol is clearly shown in this study (Table II and Fig. 3); there was an average fall in rate by $15 \%$ during exercise. Angina tended to occur at a similar heart rate in the initial test and after the placebo, but generally occurred at a lower heart rate after propranolol.

Correlation of the exercise response with the electrocardiographic findings was poor. The majority of patients with severe limitation of exercise tolerance had had major infarctions, and striking 


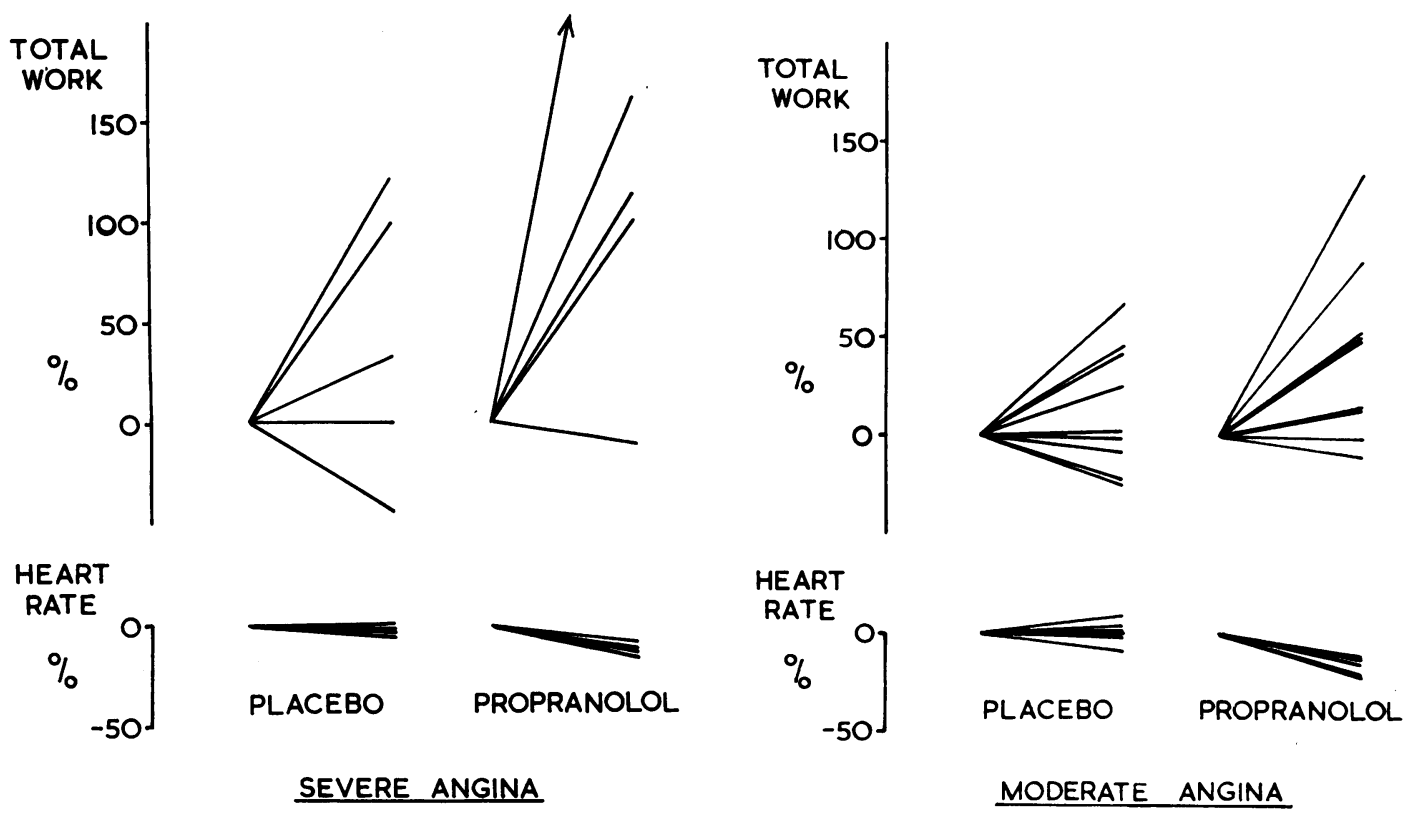

Fig. 3.-Comparison of the effects of propranolol and of a placebo injection in the two groups of patients. The change in total work in the graduated exercise test is expressed as a percentage of the initial exercise tolerance. There is a greater tendency to an increase in exercise tolerance after propranolol than after a placebo. The corresponding changes in heart rate are also shown.

increases in exercise tolerance were found in some patients in this group; many patients without infarction also showed considerable improvement. No untoward effects followed the exercise tests in these patients and there were no symptoms attributable to the drug.

\section{Discussion}

The progressive increase in work load used in the present study was selected to provide a clear-cut limit to the exercise, and the total work performed during the test is a useful measure of exercise tolerance. The considerable variation in the placebo response may be related to the competing effects of the improvement produced by training on the bicycle and the effort required to exercise repeatedly to the limit of tolerance. Similar influences would be expected to follow the injection of propranolol. The "second wind" effect is unlikely to play a significant part as a 30 -minute rest period was allowed between the tests (Wayne and Graybiel, 1934). The tendency to a greater increase in exercise tolerance after the drug suggests that a real improvement has been produced in some cases. The bradycardia produced by propranolol makes it obvious to those conducting the test that an effective drug has been given so that a "doubleblind" study cannot be carried out. The absence of any change in heart rate following the placebo indicates that there are no significant spontaneous variations in adrenergic activity.

Abnormalities of ventricular contraction have been reported in ischæmic heart disease (Messer et al., 1963), and there is evidence that the cardiac output is reduced on exercise in these patients (Foster and Reeves, 1964). Beta-adrenergic blockade has been shown to reduce myocardial contractility (Harrison et al., 1964), and might be expected to accentuate these changes. Patients with any evidence of left ventricular failure were, therefore, excluded from the present study. In this selected group of patients the improvement in exercise tolerance could not be correlated with the evidence of previous infarction or other electrocardiographic changes. Considerable improvement was noted both in patients with healed major infarction and among those with normal electrocardiograms.

Several studies have suggested that the cardiac output is relatively unaffected by beta-adrenergic blockade in normal subjects in the upright position (Bishop and Segel, 1963; Chamberlain and Howard, 1964). However, more recent work has indicated a fall in output after propranolol (Robinson et al., 1965), and we have shown a similar reduction in patients with ischæmic heart disease, both at rest and on exercise (Hamer and Sowton, 1965). A 
beneficial effect in angina is therefore associated with a reduction in tissue blood flow, at least in some parts of the peripheral vascular bed. These changes are probably secondary to interference with myocardial contractility. More efficient utilization of the available supply of oxygen to the heart as myocardial contractility is reduced (Apthorp et al., 1964) is probably the fundamental factor in the improvement in exercise tolerance.

It is clear from the present study that the heart rate is not a critical factor in the production of angina in ischæmic heart disease, as angina generally begins at a slower rate after propranolol. It has been suggested that the relative bradycardia produced by propranolol may allow longer diastolic pauses and consequently greater coronary flow. However, there is evidence that the prolongation of systole due to reduced myocardial contractility prevents any increase in diastolic time (Apthorp et al., 1964; J. Hamer, T. Grandjean, L. Melendez, and E. Sowton, 1965, unpublished work). In any case, recent studies in animals have shown that coronary flow becomes predominantly systolic in timing on exercise (Gregg, 1964).

Clinical trials of prolonged oral treatment with beta-adrenergic blocking agents in angina pectoris have been restricted by side-effects and by variations in absorption of the drug (Alleyne et al., 1963; Srivastava, Dewar, and Newell, 1964; Keelan, 1965; Gillam and Prichard, 1965), but have suggested some benefit. In our view such treatment should be confined to patients limited by severe angina but without evidence of left ventricular failure. The results of this study suggested that exercise tolerance may be increased by propranolol in these patients, but this improvement is obtained at the expense of some reduction in myocardial contractility and in peripheral blood flow.

\section{SUMMARY}

The effect of beta-adrenergic blockade with propranolol (inderal) in angina pectoris was investigated by means of a standardized exercise tolerance test. Fourteen patients without evidence of left ventricular failure, who were limited by angina in an initial test, were studied after an inert injection and after propranolol.

Five patients with severe angina showed some improvement in exercise tolerance after propranolol. Nine patients with moderate angina showed a significant increase in exercise tolerance beyond that found after the inert injection.

These findings suggest that beta-adrenergic blockade improves the exercise tolerance of some patients with angina pectoris. The possible deleterious effects of the associated reduction in myocardial contractility and in peripheral blood flow must be borne in mind in considering the therapeutic use of propranolol in patients with ischæmic heart disease.

\section{REFERENCES}

Alleyne, G. A. O., Dickinson, C. J., Dornhorst, A. C., Fulton, R. M., Green, K. G., Hill, I. D., Hurst, P., Laurence, D. R., Pilkington, T., Prichard, B. N. C., Robinson, B., and Rosenheim, M. L. (1963). Effect of pronethalol in angina pectoris. Brit. med. F., 2, 1226.

Apthorp, G. H., Chamberlain, D. A., and Hayward, G. W. (1964). The effects of sympathectomy on the electrocardiogram and effort tolerance in angina pectoris. Brit. Heart f., 26, 218.

Bishop, J. M., and Segel, N. (1963). The circulatory effects of intravenous pronethalol in man at rest and during exercise in the supine and upright positions. $\mathscr{f}$. Physiol. (Lond.), 169, $112 \mathrm{P}$.

Chamberlain, D. A., and Howard, J. (1964). The hæmodynamic effect of $\beta$-sympathetic blockade. Brit. Heart F., 26, 213.

Dornhorst, A. C., and Robinson, B. F. (1962). Clinical pharmacology of a beta-adrenergic-blocking agent (nethalide). Lancet, 2, 314.

Foster, G. L., and Reeves, T. J. (1964). Hemodynamic responses to exercise in clinically normal middle-aged men and in those with angina pectoris. $\mathcal{f}$. clin. Invest., 43, 1758

Gillam, P. M. S., and Prichard, B. N. C. (1965). Use of propranolol in angina pectoris. Brit. med. F., 2, 337.

Gregg, D. E. (1964). Coronary blood supply and oxygen usage of the myocardium. In Oxygen in the Animal Organism, ed. F. Dickens and E. Neil, p. 325 . Pergamon Press, Oxford.

Hamer, J., Grandjean, T., Melendez, L., and Sowton, G. E. (1964). Effect of propranolol (Inderal) in angina pectoris: preliminary report. Brit. med. $\mathcal{F}$., 2, 720.

, and Sowton, E. (1965). Cardiac output after betaadrenergic blockade in ischæmic heart disease. Brit. Heart F., 27, 892.

Harrison, D. C., Braunwald, E., Glick, G., Mason, D. T., Chidsey, C. A., and Ross, J., Jr. (1964). Effects of beta adrenergic blockade on the circulation with particular reference to observations in patients with hypertrophic subaortic stenosis. Circulation, 29, 84.

Holmgren, A., and Mattsson, K-H. (1954). A new ergometer with constant work load at varying pedalling rate. Scand. F. clin. Lab. Invest., 6, 137.

Keelan, P. (1965). Double-blind trial of propranolol (Inderal) in angina pectoris. Brit. med. F., $1,897$.

Messer, J. V., Levine, H. J., Wagman, R. J., and Gorlin, R. (1963). Effect of exercise on cardiac performance in human subjects with coronary artery disease. Circulation, 28, 404.

Robinson, B. F., Kahler, R. L., Epstein, S. E., and Braunwald, E. (1965). Effects of beta adrenergic blockade in man on the hemodynamic response to maximal exercise. Fed. Proc., 24, 590.

Srivastava, S. C., Dewar, H. A., and Newell, D. J. (1964). Double-blind trial of propranolol (Inderal) in angina of effort. Brit. med. F., 2, 724.

Wayne, E. J., and Graybiel, A. (1934). Observations on the effect of food, gastric distension, external temperature, and repeated exercise on angina of effort, with a note on angina sine dolore. Clin. Sci., 1, 287. 